\title{
Collaborative Relationship Analysis between Members of Apartment Construction Organizations
}

\author{
Kim, Jae-Yeob* \\ Department of Architectural Engineering, Korea National University of Transportation, Chungiu, Chungbuk, \\ 380-702, Korea
}

\begin{abstract}
The purpose of this study is to analyze collaborative relationship between members of a building construction organization. For the analysis of collaborative relationship, this researcher collected data by conducting a questionnaire survey with members of three large building construction organizations for apartment housing. The analyzed contents of collaborative relationship were the 'frequency of communication between organizational members' and their 'reliability'. According to the analysis of communication network, construction managers had low frequency of communication, whereas those responsible for each area, like construction deputy managers, had high frequency of communication. It indicates that middle managers are at the center of communication related to construction work in construction organizations. According to the analysis of reliability network, construction managers showed highest reliability, and employees at the top level in an organizational map also showed high reliability. Since they generally have a lot of experience, are some older of age, and assume responsibility for work, they are considered to receive reliability from other organizational members. This study proved that it was possible to numerically express reliability of organizational members, which is an abstract concept, and analyze it. Therefore, it is expected that the analysis result will highly be likely to be used in the area of construction management.
\end{abstract}

Keywords : building construction organization, communication network, reliability network, social network analysis

\section{Introduction}

\subsection{Research background and objective}

Cooperation between members at a construction site is a very important factor for a construction project. For smooth cooperation, building collaborative relationship between members is a prerequisite. However, a collaborative relationship is an abstract concept, and is reciprocally formed between individual relationship between members, which makes it difficult to measure and manage it[1]. The social network

Received : December 23, 2013

Revision received : January 4, 2014

Accepted : January 6, 2014

* Corresponding author : Kim, Jae-Yeob

[Tel: 82-43-841-5203, E-mail: kimjy67@ut.ac.kr]

(c)2014 The Korea Institute of Building Construction, All rights reserved.
analysis(SNA) theory introduced in a social science field provides a quantitative method to analyze relationship between people or organizations, for which many studies have been actively conducted using the theory in diverse academic fields. However, studies have not yet been actively conducted in the application of SNA in the construction management field. Therefore, this study aims to analyze collaborative relationship between members at construction sites. In addition, the findings of this research are expected to be utilized as a fundamental data for the development of a plan for enhanced cooperative relationship between members at construction sites.

\subsection{Research method and scope}

The scope of this research is limited to collaborative 
relationship between members at construction sites in Korea. In order to analyze the collaborative relationship between members at construction sites, three construction sites for apartment housing, the most common construction site, in Korea have been selected, and a survey was conducted for full-time workers at the sites. The target construction sites were a large-scale apartment building construction sites that would have at least 1,000 households, and three construction sites of large construction companies located in the metropolitan area and Chungcheong area were selected. The survey was conducted via direct visit to the sites, telephone, or e-mail, and a total of 53 questionnaires were collected from the sites. The analysis of the data collected was done using NetMiner, social network analysis software. NetMiner that provides visualized numerical data by network analysis factor is evaluated excellent in function and technical support, is one of the most widely used programs in studies related with social network analysis[1,2].

The collaborative relationship between members at the sites was quantified in this study to analyze 'frequency of communication' and 'reliability.' That is, it was analyzed based on information exchanged in the process of job performance and the level of reliability between members. The quantitative aspect(frequency of communication) and the qualitative aspect(reliability) were taken into simultaneous account. It was determined from the previous studies on collaborative relationship[3,4] and the interview results with practitioners.

\subsection{Review of previous studies}

The previous studies on collaborative relationship between members at construction sites can be largely divided into studies on 'collaborative relationship in a construction project' and those on 'utilization of SNA in the construction management field.' Of the studies on "collaborative relationship in a con- struction project,' Lee et al[5] proposed an EDI model that enables documents, serving as a communication method, to be exchanged and saved on the web in real-time in order to improve collaboration between participants. Kim et al.[6] analyzed the structural characteristics of collaborative relationship using SNA and identified the effect of the characteristics on job performance. Park et al.[7] analyzed 152 BIM-related studies previously published in Korea to understand the network between researchers. This study identified groups with collaborative relationship, and proposed that it could be utilized in selection of professionals for advice, deliberation, and evaluation. However, the studies were conducted on collaboration between participants(ordering party, constructor, designer, etc.)[5], collaboration between companies[6], and collaborative network between researchers[7]. On the other hand, this study focuses on collaborative relationship between members at construction sites, which is distinguished from other previous studies.

Of the studies of 'utilization of SNA in the construction management,' Chinowsky et al.[3] stressed the fact that efficiency and effectiveness, both of which are a conventional perspective, should be considered at once. In other words, high performance is a high likelihood when individuals focus on the success of their team beyond their personal purpose, and he put a stress on the balance between 'efficiency' and 'effectiveness.' Chinowsky et al. [8] contends that the interest of a project organization should be widely expand from efficiency to effectiveness, and that to bring high performance of a construction project team into reality improvement of communication is necessarily accompanied. Kim et al.[9] analyzed information exchange and reliability of key members of participants among ordering party, designers, builders, and supervisors(or CMers) using SNA.

The the studies using the SNA theory in the construction management field usually deal with abstract 
concept including improvement of construction performance ability[3,8] as the research objective, or collaborative relationship between participants (ordering party, designers, builders, etc.) as the research subject. On the other hand, the main purpose of this study is to perform a quantitative analysis of collaborative relationship between members at construction sites. Thus, this study is believed to be distinguished from others with respect to research subject and objective.

\section{SNA theoretical review}

SNA is a series of research method to understand the structure to have a relationship between particular individuals, groups, or organizations. In other words, SNA draws the structure between actors or the characteristics of the network form, finds the relation between them, and ultimately provides an explanation of the characteristics of the system or actions of the unit consisting of the system. The SNA technique can be categorized into density, centrality, and centralization, etc. The degree centrality employed in this study is obtained based on the sum of points directly linked to a point(actor). To be more specific, the degree centrality is quantified based on how many connections a point(an actor) has. Since this study is to quantitatively measure collaborative relationship of an individual, the degree centrality is used to evaluate the level of 'centrality' of an actor within a network. An individual who has shown to have higher centrality has many connections with others as an 'ultimate networker,' leading to a high possibility to get the information he/she wants and has more power in the end[1].

\section{Analysis of collaborative relationship be- tween members at construction sites}

\subsection{Analysis method}

\subsubsection{Questionnaire survey and summary of the sample projects}

To get a fundamental data on the collaborative relationship between members in a construction project team, a questionnaire survey was conducted for the members at construction sites. The questionnaire was composed of the personal information of a respondent, and questions about 'frequency of communication' and 'reliability.' In terms of the 'frequency of communication', and 'reliability' the respondents were asked to answer the "frequency of communication related with job performance" and "reliability on communication related with job performance," respectively, on the 5 point scale(from 1 to 5 points). The 5-point scale, most common and familiar to respondents, was used to minimize measurement error in consideration of abstract characteristics of the content(collaborative relationship) to be measured and the level of difficulty of response[10].

Table 1 is the summary of the three sample projects selected for SNA between members at construction sites for this research. The number of members at each construction site was identical to be 40 . The number of respondents at each site was more than 16 people, and 19 people in $\mathrm{C}$ division was the greatest in number. The respondents was designed to be evenly distributed in terms of position and years of experience, etc.

Table 1. Summery of sample projects

\begin{tabular}{ccccc}
\hline Project & $\begin{array}{c}\text { No. of } \\
\text { houses }\end{array}$ & $\begin{array}{c}\text { No of } \\
\text { employee }\end{array}$ & $\begin{array}{c}\text { No. of } \\
\text { respondents }\end{array}$ & $\begin{array}{c}\text { Construction } \\
\text { duration }\end{array}$ \\
\hline A & 2,422 & 47 & 18 & $2008.12-2012.10$ \\
B & 1,885 & 41 & 16 & $2011.5-2014.2$ \\
C & 2,309 & 44 & 19 & $2010.6-2013.10$ \\
\hline
\end{tabular}

\subsubsection{Analysis of degree centrality}

The degree centrality was analyzed with survey results using NetMiner. It means that the higher de- 
gree centrality one has, the more frequently he/she communicates with others and the more he/she is on the center as the result. The degree centrality is divided into in-degree centrality and out-degree centrality[1]. Here, the out-degree centrality represents the "collaborative relationship of mine with other members,' while the in-degree centrality represents the "collaborative relationship of others with me.' It is believed that the 'collaborative relationship of mine' can be more objective when judged by 'others' rather than when judged by 'oneself,' and the in-degree centrality was analyzed in this research.

\subsubsection{Relation analysis of collaborative relationship} with job area and organizational hierarchy

The degree centrality, referring to the level of collaborative relationship, was analyzed in relation with 'job area,' and 'organizational hierarchy.' Through this, the characteristics of each member and the collaborative relationship were analyzed. To analyze the position in the organizational hierarchy, the organization at the site was divided into three groups, based on which the analysis was performed.

Table 2. Grouping of construction organization members

\begin{tabular}{ccc}
\hline Group & Definition & example \\
\hline I & $\begin{array}{c}\text { Leader of construction } \\
\text { organization }\end{array}$ & Construction manager \\
& $\begin{array}{c}\text { Middle manager of } \\
\text { construction organization }\end{array}$ & $\begin{array}{c}\text { Construction deputy manager, } \\
\text { Purchasing deputy manager, } \\
\text { Managing manager, etc }\end{array}$ \\
& & Architectural assistant, \\
& & Architectural engineer, \\
III & Besides group I, II & Purchasing engineer, etc \\
\hline
\end{tabular}

\subsection{Analysis of communication network}

\subsubsection{Analysis of degree centrality}

Table 3 indicates analysis results of the communication network between members at construction sites of the sample projects using NetMiner. When one has high degree centrality, it means that he/she stands in the center of communication network related with the job within the organization. To be more specific, he/she communicates more frequently with others in relation with his/her job and thus stands in the center of information exchange related with the job.

Through the analysis of degree centrality, it was found that the person in charge of the construction (construction deputy manager) was shown to have highest value in all and each of the three projects. This indicates that communication and job are being performed in the center of construction due to its job characteristics. The person in charge of the construction who was shown to have the highest point was followed by the people who charge in each part(managing manager, equipment manager, electricity manager, architectural deputy manager, etc.).

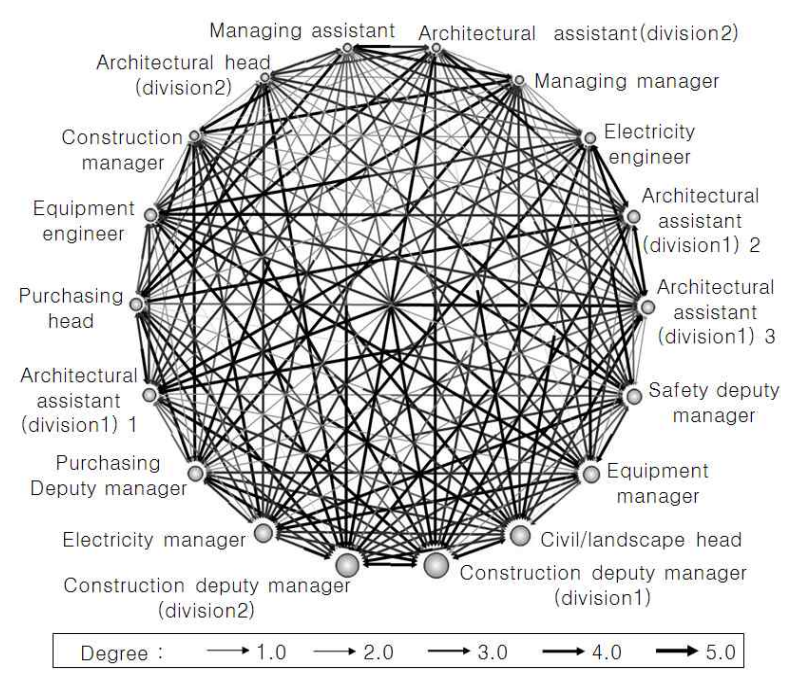

Figure 1. Communication network (project A)

Figure 1 is the visualization of communication network between employees in Project A. The size of node represents the value of degree centrality, and the straight line represents the relation of a connection. All the employees in the sample project communicate with each other, and all of them are connected, and the number of straight lines each 
Table 3. Results of degree centrality on communication network

\begin{tabular}{|c|c|c|c|c|c|}
\hline \multicolumn{2}{|l|}{ Project $\mathrm{A}$} & \multicolumn{2}{|l|}{ Project B } & \multicolumn{2}{|l|}{ Project C } \\
\hline Position & $\begin{array}{l}\text { Degree } \\
\text { centrality }\end{array}$ & Position & $\begin{array}{l}\text { Degree } \\
\text { centrality }\end{array}$ & Position & $\begin{array}{l}\text { Degree } \\
\text { centrality }\end{array}$ \\
\hline $\begin{array}{l}\text { Construction deputy } \\
\text { manager(division1) }\end{array}$ & 4.35 & $\begin{array}{l}\text { Construction deputy } \\
\text { manager(division1) }\end{array}$ & 3.93 & Construction deputy manager & 4.11 \\
\hline $\begin{array}{l}\text { Construction deputy } \\
\text { manager(division2) }\end{array}$ & 4.29 & Purchasing deputy manage & 3.93 & Design deputy manager & 3.61 \\
\hline Civil/ landscape head & 4.06 & Purchasing assistant & 3.93 & Design head & 3.61 \\
\hline Electricity manager & 3.94 & Electricity deputy manager & 3.80 & Machinery assistant & 3.61 \\
\hline Equipment manager & 3.82 & Machinery deputy manager & 3.73 & Architectural head(division2) & 3.44 \\
\hline Purchasing deputy manage & 3.76 & $\begin{array}{l}\text { Construction deputy } \\
\text { manager(division2) }\end{array}$ & 3.67 & Quality deputy manager & 3.33 \\
\hline Safety deputy manager & 3.76 & Architectural assistant(division2) & 3.60 & Architectural engineer(division2) & 3.28 \\
\hline Architectural assistant(division1) 1 & 3.65 & Safety deputy manager & 3.53 & Electricity deputy manager & 3.22 \\
\hline Architectural assistant(division1) 3 & 3.65 & Architectural head(division1) & 3.53 & Purchasing head & 3.22 \\
\hline Purchasing head & 3.59 & Architectural assistant(division1) & 3.47 & Architectural assistant(division3) & 3.17 \\
\hline Architectural assistant(division1) 2 & 3.59 & Machinery assistant & 3.33 & Architectural assistant(division2) & 3.17 \\
\hline Equipment engineer & 3.59 & Managing deputy manager & 3.27 & Architectural engineer(division3) & 3.17 \\
\hline Electricity engineer & 3.47 & Electricity engineer & 3.27 & Electricity engineer & 3.17 \\
\hline Construction manager & 3.35 & Construction manager & 3.20 & Machinery manager & 3.06 \\
\hline Managing manager & 3.29 & Architectural head(division2) & 3.20 & Purchasing assistant & 3.06 \\
\hline Architectural head(division2) & 3.29 & Purchasing engineer & 3.20 & Architectural assistant(division1) & 2.94 \\
\hline Architectural assistant(division2) 1 & 3.29 & & & Civil/ landscape manager & 2.89 \\
\hline Managing assistant & 3.29 & & & Safety head & 2.89 \\
\hline & & & & Safety engineer & 2.56 \\
\hline
\end{tabular}

employee has is as many as the number of employees. The bold line shown in Figure 1 shows the degree centrality to be 4 or 5 , and the bigger the node size is, the bolder the straight line is.

\subsubsection{Job area and communication network}

In Table 4, in terms of the employee who has the highest degree centrality, architectural deputy manager(division1) was shown in Project A, architectural deputy manager(division1), managing manager, and managing under manager in Project B, and architectural deputy manager(division1) in Project C. In Project B, except for managing deputy manager and managing under manager, it was common that the job area that was shown to be highest in score of degree centrality was the construction. In addition, the degree centrality of each division of Projects A, $\mathrm{B}$, and $\mathrm{C}$ was summed and averaged, and then top 30 percent was analyzed. Through the analysis, the order of civil/landscape (4.06), safety(3.76), and construction(3.73) was found to have highest in score in Project A, the order of managing(3.69), construction(3.53), and electricity and $\operatorname{safety}(3.53)$ was revealed to have highest in score in Project $B$, and the other of others(architecture)(3.61), construction and quality(3.33) was shown to have highest in score in Project C. Construction was found in common on the top 30 percent of the three sample projects. Therefore, the job that has the highest communication constructability in a construction site was analyzed as construction.

\subsubsection{Position in the organization and communication network}

From the analysis results of degree centrality of communication network, and three groups in the organization analyzed in Table 3 , the employees that have the highest score of degree centrality in all the Projects A, B,C was included in Group II in the organization. The employees in Group II was shown to have higher score in degree centrality compared to those in Group I who have a higher position in the organization. In addition, the average of degree 
centrality by group in the organization was shown high in the order of Group II, Group III, and Group I in all the three sample projects. The employees in Group II were shown to have the most frequent communication related with the job at the site and to be in the center of the communication.

\subsection{Analysis of the reliability network}

\subsubsection{Analysis of degree centrality}

Table 4 indicates the analysis results of the reliability network between members at construction sites of the three sample projects using the NetMiner program. In the analysis of reliability network, the questionnaires on which respondents checked the same point in the questions of reliability to other employees were excluded. In the process of the survey, there were some respondents who do not feel free to evaluate reliability to their colleagues, and they were excluded. Therefore, a total of 45 questionnaires were used for the analysis. The analysis results of the reliability network were shown relatively higher than those of the communication network in Table 4. This may result from the burden to evaluate reliability of colleagues and the organizational culture with strong bond. The employee that has the highest degree centrality on reliability network was shown as construction manager in Projects A and B. In Project $\mathrm{C}$ from which the questionnaire of the construction manager was not collected, construction deputy manager for the above ground part was shown to get the highest score. Construction manager got a lower score in the communication network, while the highest score in the reliability network. This means that construction managers communicates with others relatively less frequently, but shows the highest reliability.

Figure 2 is a visualization of reliability network of employees at the site of Project A. The size of a node represents the value of degree centrality, and the line shows the connection, and the bold line is 4 or 5 level of connection, which means high

Table 4. Results of degree centrality on reliability network

\begin{tabular}{|c|c|c|c|c|c|}
\hline \multicolumn{2}{|l|}{ Project $A$} & \multicolumn{2}{|l|}{ Project B } & \multicolumn{2}{|l|}{ Project C } \\
\hline Position & $\begin{array}{l}\text { Degree } \\
\text { centrality }\end{array}$ & Position & $\begin{array}{l}\text { Degree } \\
\text { centrality }\end{array}$ & Position & $\begin{array}{l}\text { Degree } \\
\text { centrality }\end{array}$ \\
\hline Construction manager & 4.85 & Construction manager & 4.91 & Construction deputy manager & 4.22 \\
\hline Managing manager & 4.69 & Purchasing deputy manager & 4.64 & Design deputy manager & 4.17 \\
\hline Purchasing deputy manager & 4.54 & $\begin{array}{c}\text { Construction deputy } \\
\text { manager(division1) }\end{array}$ & 4.45 & Quality deputy manager & 4.00 \\
\hline Purchasing head & 4.54 & $\begin{array}{l}\text { Construction deputy } \\
\text { manager(division2) }\end{array}$ & 4.36 & Design head & 4.00 \\
\hline $\begin{array}{l}\text { Construction deputy } \\
\text { manager(division1) }\end{array}$ & 4.46 & Machinery deputy manager & 4.36 & Machinery manager & 3.78 \\
\hline $\begin{array}{l}\text { Construction deputy } \\
\text { manager(division2) }\end{array}$ & 4.38 & Safety deputy manager & 4.36 & Electricity deputy manager & 3.72 \\
\hline Electricity manager & 4.08 & Electricity deputy manager & 4.27 & Architectural head(division2) & 3.56 \\
\hline Civil/ landscape head & 4.08 & Architectural head(division2) & 4.27 & Purchasing head & 3.44 \\
\hline Safety deputy manager & 3.77 & Purchasing assistant & 4.27 & Machinery assistant & 3.33 \\
\hline Architectural assistant(division2) & 3.69 & Architectural assistant(division2) & 4.09 & Civil/ landscape manager & 3.06 \\
\hline Architectural head(division2) & 3.54 & Architectural assistant(division1) & 3.82 & Purchasing assistant & 3.06 \\
\hline Architectural assistant(division1)1 & 3.54 & Purchasing engineer & 3.73 & Safety head & 3.00 \\
\hline Architectural assistant(division1)2 & 3.46 & & & Electricity engineer & 3.00 \\
\hline Electricity engineer & 3.38 & & & Architectural assistant(division1) & 2.94 \\
\hline & & & & Architectural assistant(division3) & 2.94 \\
\hline & & & & Architectural assistant(division2) & 2.89 \\
\hline & & & & Architectural engineer(division3) & 2.78 \\
\hline & & & & Architectural engineer(division2) & 2.67 \\
\hline & & & & Safety engineer & 2.61 \\
\hline
\end{tabular}


reliability. As the size of the node becomes larger, there are more bold lines found.

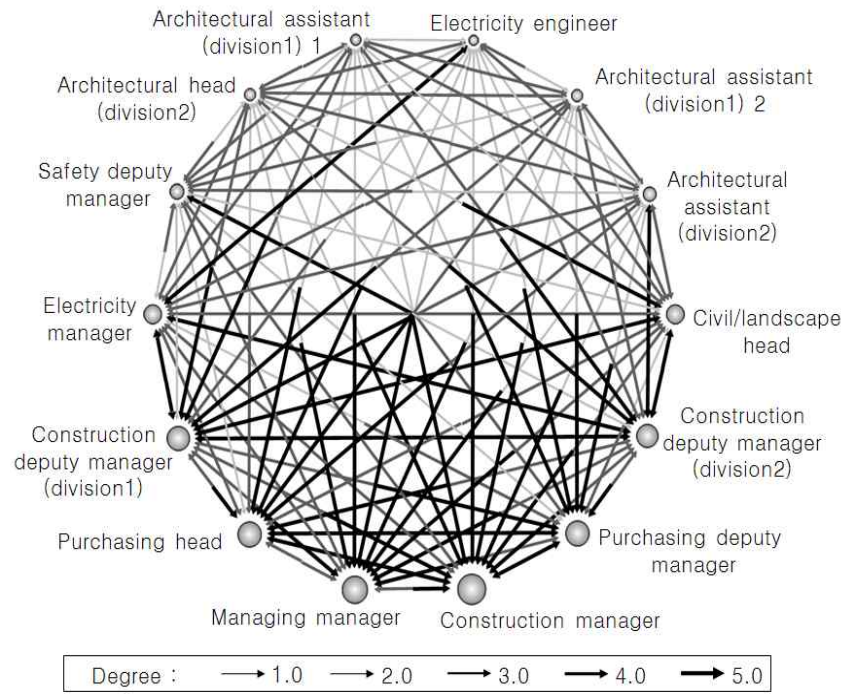

Figure 2. Reliability network (project A)

\subsubsection{Job area and reliability network}

By job area the value of degree centrality on the reliability network by job area showed no clear correlation between job area and reliability. By construction site, all the values of reliability by job area in each project were summed and averaged, and then the top 30 percent was analyzed. From the results, construction manager, others(manager), and official affairs were shown to have a high score in that order in Project A, the construction manager, safety and electricity were shown to have a high score in that order in Project B, and others(design), quality, and electricity was shown to have a high score in that order in Project C.

\subsubsection{Position on the organization and reliability net- work}

Through the analysis of the reliability and the position in the organization, the higher position one has, the higher value of reliability one appears to have. By group, Projects A and B showed that Group I had the highest value in terms of reliability, while Project
C showed that Group II, the highest position in the organization, appeared to be highest in score because the questionnaire of Group I(construction manager) was not collected. In order to find out reliability and the position in the organization, the average of reliability by Group I, II, and III was calculated, and the result was found to be in the order of Group I, Group II, and Group III in all of the three sample projects. It is analyzed that the employees with a higher position in the organization overall has a higher level of reliability.

\section{Conclusion}

In this study the collaborative relationship between members at sites of construction projects. The collaborative relationship was analyzed by focusing on two factors: the level of information exchange with other employees in the organization and reliability to others.

Through the analysis of communication network, the degree centrality was shown highest in the persons in charge of each area like construction deputy manager, in construction by job, and in the middle group in the organization. On the other hand, the construction manager ranked at a lower rung of the communication network. This is because the construction is given a lot of weight at a construction site, and since middle managers are between construction managers and employees, they play the central role in communication.

Next, in the analysis of the reliability network, construction managers were shown to get the highest score, and the employees with a higher position was evaluated to have a higher score. This implies that construction managers and employees with a higher position generally have many experiences, and take more responsibility for the jobs so that they often win other workers' trust. 
It is identified that the abstract concept of the level of communication between members at construction sites of construction projects and reliability can be numerically analyzed in this study. Therefore, when using the SNA employed in this study, the collaborative relationship between members at construction sites is believed to be assessed. In addition, the findings of this research can be utilized as fundamental data of a plan for building of enhanced collaborative relationship in the organization at construction sites.

\section{Acknowledgement}

The research was supported by a grant from the Academic Research Program of Korea National University of Transportation in 2013.

\section{References}

1. Kim YH. Sahoiyeon'gyeolmangbunseok[Social network analysis]. 3rd ed. Seoul (Korea): Pakyoungsa; c2011. Chapter 3, Core concept of social network analysis; p. 63-70. Korean

2. NetMiner[Internet]. Seoul (Korea): CYRAM; 2000 [updated 2013 Mar 19; cited 2013 Oct 15]. Available from: http://www. netminer.com

3. Chinowsky P, Diekmann J, Galotti V. Social network model of construction. ASCE journal of construction engineering and management. 2008 Oct;134(10):804-12.

4. Kratzer J, Leenders R.T.A.J, Van Engelen J.M.Ll. The social network among engineering design teams and their creativity. International journal of project management. 2009 Sep;28:428-36.

5. Lee HS, An SJ, Son BS, Jang MH. Development of web-based electronic data interchange model to improve the collaboration of participants in construction project. Journal of the architectural institute of Korea. 2003 Jun;19(6):151-60.

6. Kim KS, Shin TH. Strategic alliance networks in Korean construction industry: network structure and performance of firms. Korean journal of construction engineering and management. 2009 Jul;10(4):151-64.

7. Park YS, Cho YJ, Cheong JH. A study on architectural expert network using social network analysis. Journal of the architectural institute of Korea. 2010 Oct;26(10):147-54.
8. Chinowsky P, Diekmann J, O'Brien J. Project organizations as social networks. ASCE journal of construction engineering and management. 2010 Apr;136(4):452-8.

9. Kim JY, No ST. Characteristics of subcontracting networks in Korean apartment constructions. Applied mechanics and materials. 2012 May;174-177:2725-8.

10. Chae SI. Sahoi'gwahakjosabangbeobron[Social science search methodology]. 3rd ed. Seoul (Korea): Bnmbooks; c2013. Chapter 5, Measurement; p. 153-7. Korean 